\title{
A closer look at organ donation after cardiocirculatory death in Canada
}

\author{
Andrew Baker, MD
}

Published online: 27 August 2009

(C) Canadian Anesthesiologists' Society 2009

The world of organ and tissue transplantation is one of the major successes and good-news stories in medicine. Central to the success of transplantation is the process of organ and tissue donation. While donation is valued highly by Canadians, there are still many important pressing issues relevant today that warrant our attention and creative energy. These include the lack of community education in general about organ and tissue donation and specifically education that is culturally effective; the inconsistent approach of health care workers in appropriately making the option of donation known; the reluctance of families to discuss such topics in advance; the organization and funding of health care and its impact in preventing many patients from actualizing their potential donation wishes; the inexplicable gap between the actual and potential tissue donation rates-especially as it relates to the need for importation; and the geographic variation in donation rates within Canada and what this represents in terms of equity and quality of care. Canadians are also concerned about illegal and immoral practices internationally.

Our practice in anesthesiology and critical care is aimed at preserving life and restoring health wherever possible. Many of us spend our professional lives going to great lengths to save severely critically ill people. When organ donation becomes relevant, it is no surprise that the approach of these physicians towards the topic is a remarkably careful one, with the ethical aspects and implications clearly central. There is a focused accountability and advocacy for the critically ill patient that carries forward even after death. Many of us are struck by the way

\footnotetext{
A. Baker, MD ( $\square)$

Department of Critical Care, St. Michael's Hospital, 4010 Bond

Wing, 30 Bond Street, Toronto, ON M5B 1W8, Canada

e-mail: bakera@smh.toronto.on.ca
}

in which patients, often through their families, impress upon us their sense of the value and importance of organ and tissue donation. Furthermore, so many anesthesiologists and critical care physicians also share the values of organ and tissue donation as the potential for life-promoting benefit to other Canadians is part of their professional and personal orientation.

Over the last three decades or so, the vast majority of deceased organ donation has occurred following what is commonly referred to as brain death of the donor. For the last few years, and many more in the US, there has been a steady increase in the percentage of deceased donations that have occurred following the donor being identified as dead by cardio-respiratory criteria. After death by neurological criteria, a number of hours can elapse and still allow for successful donation because of the preserved circulation, oxygenation and organ viability. This is not the case with donation after death by cardio-circulatory criteria (DCD). The health care team must be ready and mobilized prior to the time of death in order for the organs to be donated promptly soon after death.

While DCD had occurred in Canada several years ago, its re-introduction came after a national forum and international benchmarking in 2005 sponsored by the Canadian Council on Donation and Transplantation (CCDT) that culminated in a published set of recommendations. ${ }^{1}$ With this publication, for many of us, the question from families about why donation was not happening after an anticipated cardio-respiratory death became more difficult to answer.

The introduction of DCD into Canadian hospitals has fulfilled the donation wishes of many patients who would otherwise have died, without a chance to express this value. Indeed, $19 \%$ of all deceased donors in Ontario last year were DCD donors. The introduction of DCD has been accompanied by healthy and constructive discussion on various 
potential issues. The logistics of DCD have also been a starting point for many health care workers and bio-ethicists to re-look at current practices. Accordingly, the introduction of DCD into many hospitals has sparked some debates. These debates, however, have similar premises: the respect for the inherent value of life including of course, those with a relatively short prognosis; and the value that people can create through the desire to donate organs and tissues.

Some have expressed concern that because of the variability in the determinants used to make a decision regarding withdrawal of life-sustaining therapy, the presence of a DCD program in a hospital may introduce a conflict of interest in making this decision. ${ }^{2}$ Most practitioners feel that this question about patient choices for withdrawal of life-sustaining therapy should precede and be independent of any consideration of DCD.

Another set of questions has focused on the time of the moment of death. Clearly the donation of some organs is incompatible with ongoing life of the donor. Thus, the question of the time of the moment of death becomes very important in order to identify when donation can commence. In this issue of the Journal, a special article by Downie et $a l .{ }^{3}$ provides one legal perspective and some recommendations related to the definition and determination of death and the practice of DCD in Canada.

The CCDT forum arrived at the recommendation that death could be identified after $5 \mathrm{~min}$ of continuously observed absent circulation that followed apnea and circulatory arrest in patients for whom a previous independent decision to withdraw of life-sustaining therapy had already been made. The recommendations of this forum were arrived at by a consensus of a broad range of experts in law, medicine and bioethics and based on a combination of physiologic rationale and respect for consent law. Other perspectives include the requirement for physiologic certainty without reference to consent. Part of the concern here is that we all have had the experience of reviving people from cardiac arrest after more than 5 min of down time. Further there have been a few reports of spontaneous return of circulation following the termination of CPR for over 5 min. However, in these situations the physiology is quite different from the cases of withdrawal of life-sustaining support. In the latter, patient selection, pre-existing physiology that is inconsistent with sustaining life, the evolution of severe hypoxia, the failure of both the brainstem and the cardiovascular system on the basis of the combination of hypoxia and pre-existing physiology, all in combination with a further $5 \mathrm{~min}$ of arrested circulation, result in a physiologic state that many practitioners understand as functionally irreversible and will define as death. There are no reports of spontaneous return to life in this situation. Thus, this formed the clinical and physiological basis for the practice of declaring death at this point in time and formed part of the rationale of the recommendations in the CCDT forum.

Downie et al. suggest that the issue of diagnosing death is highly charged, and that practitioners are at risk of criminal charges or costly litigation because of the uncertainties that the authors have raised around the definition of death. Many practitioners, who have cared for people at the end of life in a critical care setting, and those who have cared for DCD donors, may find this article to be disconnected from their lived experience.

We all hold Canadian laws and its criminal and judicial system in high regard and trust. In this respect, it is surprising that this legal analysis arrives at a conclusion that the current practice puts health care workers at such risk. One is left with the impression that the implications made in this article would benefit from other perspectives and analysis_-including legal, bio-ethical and clinical.

\section{Le don d'organes après un décès cardiocirculatoire au Canada: un examen plus approfondi}

Le monde de la transplantation d'organes et de tissus compte parmi les réussites et les histoires à succès les plus importantes de la médecine. Le processus du don d'organes et de tissus se trouve au centre d'une transplantation réussie. Bien que le don d'organes occupe une place de choix dans le cœur des Canadiens, nombre de questions importantes et pertinentes demeurent encore, lesquelles justifient que nous déployions attention et énergie créatrice. Parmi ces questions, citons le manque d'éducation de la population au sujet du don d'organes et de tissus en général, et en particulier le manque d'éducation ayant un impact véritable d'un point de vue culturel; les approches inégales des travailleurs de la santé en ce qui touche à la possibilité d'un don d'organes; la réticence des familles à discuter de tels sujets à l'avance; l'organisation et le financement des soins de santé et leurs répercussions, qui pourraient empêcher certains patients de concrétiser leur désir potentiel de don d'organes; l'écart inexplicable entre les taux réels et potentiels de dons de tissus, particulièrement en regard du besoin d'importations; et les variations géographiques en matière de taux de dons au sein du Canada, ainsi que ce que cette réalité implique en termes d'équité et de qualité des soins. Les Canadiens sont également préoccupés par les pratiques illégales et immorales à l'œuvre sur la scène internationale.

En anesthésiologie et en soins critiques, l'objectif de notre pratique est de préserver la vie et de rétablir la santé à chaque fois que cela est possible. Nous sommes nombreux 
à passer notre vie professionnelle à tout faire pour sauver des personnes très gravement malades. Lorsque la question du don d'organes se pose, il n'est dès lors pas surprenant que ces médecins adoptent une approche très prudente du sujet, les aspects et implications éthiques se trouvant clairement au centre de leurs préoccupations. En effet, le médecin est responsable envers et pour le patient gravement malade et ce, même après son décès. Nous sommes nombreux à être frappés par la manière dont nos patients, souvent par l'intermédiaire de leurs familles, nous transmettent l'importance et la valeur qu'ils accordent au don d'organes et de tissus. Pour cette raison, nombre d'anesthésiologistes et de médecins des soins critiques partagent eux aussi les valeurs de leurs patients concernant le don d'organes et de tissus, étant donné que la possibilité de favoriser la vie d'autres Canadiens fait partie intégrante de leur orientation professionnelle et personnelle.

Au cours des trente dernières années, la grande majorité des dons d'organes de personnes décédées est survenue après ce que l'on nomme communément la mort cérébrale du donneur. Ces dernières années, nous avons assisté à une augmentation constante du pourcentage de dons de personnes décédées survenant après que le donneur a été déclaré mort selon des critères cardiorespiratoires. Cette situation est encore plus manifeste aux États-Unis. À la suite d'un décès déclaré sur la base de critères neurologiques, plusieurs heures peuvent s'écouler sans que cela n'entrave la réussite d'un don grâce à la préservation de la circulation, de l'oxygénation et de la viabilité des organes. Mais il n'en va pas de même lors du don d'organes suivant un décès cardiocirculatoire (DDC). L'équipe soignante doit être prête et mobilisée avant le décès afin que les organes puissent être donnés dans les plus brefs délais suivant le décès.

Bien qu'il y ait eu des DDC au Canada il y a plusieurs années, leur réintroduction est survenue à la suite d'un forum national et d'une analyse comparative internationale en 2005 financés par le Conseil canadien pour le don et la transplantation (CCDT) et aboutissant à la publication d'un ensemble de recommandations. ${ }^{1}$ À la suite de cette publication, il est devenu plus difficile pour nombre d'entre nous de répondre à la question des familles concernant la raison pour laquelle il n'y avait pas de don après un décès cardiorespiratoire anticipé.

L'introduction du DDC dans les hôpitaux canadiens a répondu au désir de don de nombreux patients qui seraient autrement décédés sans que ce désir n'ait pu se concrétiser. En effet, $19 \%$ des donneurs décédés l'année dernière en Ontario étaient des donneurs DDC. L'introduction du DDC a été accompagnée de discussions saines et constructives concernant plusieurs questions potentiellement épineuses. La logistique nécessaire au DDC a également servi de point de départ à plusieurs travailleurs de la santé et bioéthiciens et leur a permis de réévaluer les pratiques actuelles. Par conséquent, l'introduction du DDC a lancé des débats dans plusieurs hôpitaux. Ces débats ont cependant des postulats semblables : le respect de la valeur inhérente de la vie, y compris, bien entendu, les vies avec un pronostic relativement court; et la valeur qui peut être créée par les personnes grâce à leur désir de faire don de leurs organes et tissus.

Certains ont exprimé leur crainte que, en raison de la variabilité des facteurs déterminants utilisés pour prendre une décision quant à l'interruption des traitements de maintien de la vie, l'existence d'un programme de DDC dans un hôpital crée un conflit d'intérêt lors de la prise de cette décision. ${ }^{2}$ La plupart des praticiens sont d'avis que la question du choix des patients concernant l'interruption des traitements de maintien de la vie devrait précéder et être traitée indépendamment de toute considération de DDC.

D'autres questions ont porté sur le moment de l'heure du décès. Il est évident que le don de certains organes est incompatible avec la continuation de la vie du donneur. Dès lors, la question du moment de l'annonce de décès devient essentielle afin de déterminer quand un don peut être initié. Dans ce numéro du Journal, un article spécial par Downie et coll. ${ }^{3}$ propose une perspective légale et des recommandations liées à la définition et la détermination du décès ainsi qu'à la pratique du DDC au Canada.

Le forum du CCDT est parvenu à la recommandation suivante : le décès peut être prononcé après 5 minutes d'absence de circulation observée en continu à la suite d'une apnée et d'un arrêt circulatoire chez les patients pour lesquels une décision indépendante et antérieure d'interrompre le traitement de maintien de la vie avait déjà été prise. Les recommandations de ce forum ont été établies par consensus par une vaste gamme d'experts dans les domaines du droit, de la médecine et de la bioéthique, et sont basées sur une combinaison de justifications physiologiques et de respect du droit de consentement. D'autres perspectives comprennent la nécessité d'obtenir une certitude physiologique indépendamment du consentement. Une partie des inquiétudes dans une telle situation est liée au fait que nous avons tous fait l'expérience de patients réanimés après un arrêt cardiaque de plus de 5 minutes. De plus, nous n'avons que peu de cas rapportant une reprise spontanée de la circulation après l'interruption de RCR pour plus de 5 minutes. Toutefois, la physiologie est bien différente dans ces situations par rapport aux cas d'interruption du traitement de maintien de la vie. Dans le second cas, la sélection des patients, une physiologie préexistante allant à l'encontre du maintien de la vie, l'évolution d'une hypoxie grave, la défaillance du tronc cérébral et du système cardiovasculaire selon une combinaison d'hypoxie et de physiologie préexistante, le tout associé à 5 minutes supplémentaires de circulation arrêtée, ont pour résultat un 
état physiologique que nombre de praticiens comprennent comme étant irréversible d'un point de vue fonctionnel et qu'ils définiront comme le décès. Et il n'existe aucun compte-rendu de retour spontané à la vie dans une telle situation. Par conséquent, cette constatation est le fondement clinique et physiologique de notre pratique de déclaration du décès à ce moment-là, et fonde en partie la justification des recommandations émises par le forum du CCDT.

Selon Downie et coll., la question du diagnostic de décès est très chargée et les praticiens courent le risque d'accusations au pénal ou de litiges dispendieux en raison des incertitudes émises par les auteurs quant à la définition du décès. Nombre de praticiens, qu'il s'agisse de ceux qui ont pris soin de personnes en fin de vie dans un cadre de soins critiques, ou de ceux qui ont pris soin de donneurs DDC, pourraient trouver cet article bien différent de leur expérience vécue.

Nous attachons tous une grande valeur aux lois canadiennes ainsi qu'au système pénal et judiciaire de notre pays, et nous y plaçons notre confiance. C'est pourquoi il est frappant que notre analyse légale parvienne à la conclusion que la pratique actuelle met les travailleurs de la santé dans un tel danger. Une impression demeure : que les implications de cet article pourraient bénéficier d'autres perspectives et analyses, notamment d'un point de vue légal, bioéthique et clinique.

Acknowledgment Dr. Baker is a member of the Board of Directors of Trillium Gift of Life Network and is a member of the Canadian Blood Services Steering Committee on Organ and Tissue Donation and Transplantation.

Competing interests None declared.

\section{References}

1. Shemie SD, Baker AJ, Knoll G, et al. National recommendations for donation after cardiocirculatory death in Canada. Donation after cardiocirculatory death in Canada. CMAJ 2006; 175: S1-24.

2. Doig CJ. Is the Canadian health care system ready for donation after cardiac death? A note of caution. CMAJ 2006; 175: 905.

3. Downie J, Kutcher M, Rajotte C, Shea A. Eligibility for organ donation: a medico-legal perspective on defining and determining death. Can J Anesth 2009; 56. doi:10.1007/s12630-009-9130-x. 